\title{
THE IMPLEMENTATION OF LINEAR PROGRAM IN DETERMINING PRODUCT COMBINATIONS TO ACHIEVE OPTIMAL PROFITS IN NGANJUK “SYUKUR” TILE HOME INDUSTRY
}

\author{
Achmad Zaki \& Sinollah \\ Fakultas Ekonomi dan Ilmu Sosial, Unira Malang, Indonesia
}

\begin{abstract}
This study aims to investigate the application of linear programming in determining the combination of products that can produce optimal profits in Nganjuk "Syukur" tile home industry. This is a descriptive study whose data are obtained from interviews, field observations and documentation. For data analysis, this present study uses linear programming analysis with the simplex method. Time series analysis is used as a basis for forecasting for the future (linear trend with the method of small squares). To determine the optimal product combination in linear programming, the objective and function are limited. This study confirms that Max Z $=216,250 \mathrm{X} 1+156,000$ $\mathrm{X} 2+1,363,000 \mathrm{X} 3$ where the combination of tile $(\mathrm{X} 1)=341$ per day; Pilang Karang Tile $(\mathrm{X} 2)=$ 448 per day and Wuwung Tile $(\mathrm{X} 3)=203$ per day, the benefit is Rp. $=418,937,000$. The company has to pay attention to the combination of products especially when the company produces more than one type of product and limiting factors.
\end{abstract}

Keywords: linear program, product combination, optimal profit, home industry

\section{INTRODUCTION}

Basically every company has the same goal, that is, to ensure its survival through growth and profitability. Growth and profit can be used as a measure of the company's success in carrying out activities related to its operations. The company works efficiently if the company can maintain its survival to develop and be able to compete. Companies that produce a product must design an effective and efficient work system in order to produce optimal profits. To achieve this goal requires a production plan owned by the company (Sofyan, 1990; Arifinal et al, 1994).

Production area is the total number or volume of production that requires careful planning. Without planning, it is difficult for compa-

*Corresponding Author.

e-mail: sinollah@gmail.com nies to ascertain the number of products that must be produced, the number of productions can be too large or even too small (Ahyari, 1986). One important department is the production department. The function of this department is to determine the level of production of each type of product precisely and pay attention to the factors of production that are available. Determination of the right amount of production is a key to getting the maximum profit for a business (Sari, 2015). Each product is limited by machine capacity, raw materials, labor and market demand.

The company has unlimited resources. Meanwhile, the number of market demand is increasing day by day. Market competition conditions are getting tougher and this situation reduces opportunities to achieve or realize com- 
Achmad Zaki \& Sinollah / The Implementation of Linear Program in Determining Product Combinations to Achieve Optimal Profits in Nganjuk "Syukur” Tile Home Industry / JEE, Vol. 9, No. 1, March 2020, pp 43-52

pany targets. To fulfill this demand, companies must be able to utilize resources effectively and efficiently to produce more than one type of product. Therefore, companies must be able to determine the optimal combination of products: in the form of the number and type of products that must be produced by considering various limitations of the company's production factors to achieve maximum profit.

The company considers that the products produced by more than one type are ideal. If one type of product has a large sale, the profit is also large. Actually not the case. A product that has a large sales will not necessarily provide a large profit. Vice versa. When a product with omet sales is low, the situation does not necessarily provide a low profit. Therefore companies need a combination of products to achieve optimal profits.

To face competition and anticipate the number of market demand sufficient to be fulfilled, then the determination of the optimal product combination needs to be carried out so that the company can more easily realize its objectives. If the company does not make a combination of products, it can be said that the company will lose consumers or lose some of its market potential. As a result the company loses the opportunity to achieve profits or large profits.

Companies must be able to utilize facilities and factors of production effectively. Determining the combination of products is not enough just to rely on the foresight and sharpness of a manager's instincts. This requires precise calculations. So to determine the combination of products, we need a linear programming tool with the simplex method: the approach in optimal profits (Suryani, 2006; Suprapti and Bodroastuti, 2012; Windarti, 2013; Hakim et al. 2018; Krisnadewi and Setiawan, 2018). Linear programming generally aims to maximize profits, such as Howara (2011), Rahayu et al (2014) and Ujianto (2016) research. On the other hand, linear programming aims to drink the total cost, as in Veselovska (2014, Schreider (2015) and Govindan and Sivakumar (2016) research. Some studies also conclude that optimization methods can be applied both technically and economically. Jahandided (2012) regarding fortopolio, Meng et al.'s research (2015) on train rescheduling, Vijayvargy (2015) research on supply chain, and Karo research (2016) with the aim of minimizing costs.

The purpose of this study is to determine the application of linear programming in determining the combination of products that can achieve optimal profits in the "Syukur" Nganjuk tile home industry. Based on the description above, this study is entitled "The Application of Linear Programming in Determining Product Combinations to Achieve Optimal Profits in the" Syukur "Nganjuk Tile Home Industry.

\section{METHOD}

This is a descriptive study that aims to explain or reveal the characteristics of the variables and aspects that are relevant to the phenomenon being studied (Riduan and Kuncoro, 2008). The research site was conducted at the Nganjuk "Syukur" tile home industry, precisely in Kaloran Village, Ngronggot District, Nganjuk Regency.

Data from this research include secondary data: data on raw material requirements, data on the number of workers, production data and engine capacity data and other secondary data. Secondary data were obtained from literature studies. 
Achmad Zaki \& Sinollah / The Implementation of Linear Program in Determining Product Combinations to Achieve Optimal Profits in Nganjuk "Syukur” Tile Home Industry / JEE, Vol. 9, No. 1, March 2020, pp 43-52

To analyze data, this study uses quantitative data. Linear programming with the simplex method is used as an analysis tool (Mulyono, 2004; Heizer and Render, 2006; Agustina et al., 2013). To determine the demand constraints, this study uses a series analysis whose purpose is to predict the future (linear trend with the method of small squares).

\section{FINDINGS}

The products of the Nganjuk "Syukur" tile company are types of tiles, including:

1) Pressed tiles: this type of tile has a length of $29 \mathrm{~cm}$ and a width of $22 \mathrm{~cm}$ printed with machine tools and the material used is red soil, black soil and sand.

2) Coral tiles: Namely this type of tile is more modern in shape and better, its quality is better than that of tile press and also lasts longer. This tile has a length of $31 \mathrm{~cm}$ and width $23 \mathrm{~cm}$. bias is also a message to be colored according to consumer tastes and the materials used are red soil, black soil, sand and kaolin.

3) Wuwung roof tiles: that is, tiles that are produced are less than other types of roof tiles because the needs of each house are also very small so that they are rarely purchased (Purchasing a small amount). Wuwung roof tile has a length of $29.5 \mathrm{~cm}$ and a width of $23 \mathrm{~cm}$ and the materials used are red soil, black soil, sand and kaolin.

Table 1 Genteng "Syukur" Nganjuk Company Products Target

\begin{tabular}{ccccccc}
\hline \multirow{2}{*}{ Year } & \multicolumn{2}{c}{ G. Press } & \multicolumn{2}{c}{ G. Karang Pilang } & \multicolumn{2}{c}{ G. Wuwung } \\
\cline { 2 - 7 } & Target & Realization & Target & Realization & Target & Realization \\
\hline 2013 & 111,000 & 111,500 & 126,000 & 126,000 & 126,000 & 51,100 \\
2014 & 122,000 & 122,250 & 127,000 & 127,000 & 127,000 & 53,500 \\
2015 & 126,000 & 126,000 & 131,000 & 131,000 & 131,000 & 56,000 \\
2016 & 129,000 & 129,700 & 133,000 & 133,100 & 133,000 & 57,000 \\
2017 & 133,000 & 133,000 & 136,000 & 136,700 & 136,000 & 60,000 \\
\hline
\end{tabular}

Source: Genteng “Syukur” tile company Nganjuk, 2018
To market its products with the right distribution channels will help the development of a company (Kotler and Lane, 2007). If the distribution channels used by the company run well, the marketing areas of the company's production will also be able to run well (Sinollah, 2012). "Syukur" tile companies in marketing their finished products to the hands of end consumers use two distribution channels, namely direct and indirect channels through intermediaries. "Syukur" tile company produces more than one type of product. Thus each type has different prices, among others:

a. Pressed tiles: Rp 750,000 thousand

b. Coral tile: Rp 800,000 per thousand

c. Wuwung roof tile: Rp 2,000,000 per thousand

The working days and hours in "Syukur" tile companies are as follows.

Table 2 Working Days and Hours

\begin{tabular}{lcc}
\hline \multicolumn{1}{c}{ Day } & $\begin{array}{c}\text { Working } \\
\text { Hours }\end{array}$ & Break \\
\hline Monday-Saturday & $07.30-15.30$ & $12.00-13.00$ \\
Friday & $07.30-15.30$ & $11.00-13.00$ \\
\hline
\end{tabular}

Source: "Syukur" tile company Nganjuk, 2018

The company is very dependent on funds/ capital to run its business. $50 \%$ of this company is own capital and $50 \%$ is loan capital The variables of this study are the factors that play a role in the events or symptoms to be studied. There are several components used in the study:

1. Decision Variable: to facilitate the formulation of linear programming, the decision variable in the tile company "Gratitude" is: $\mathrm{X} 1=$ Number of tile press produced $\mathrm{X} 2=$ Number of coral tiles produced $\mathrm{X} 3$ = Number of wuwung tiles produced

2. Purpose Function (Product Combination): to show the number of tile products produced 
by the company annually. The purpose of the product combination is to maximize the profits of the thousand in a year. The objective function is to contribute to the profit of one thousand tiles per year6a (Zulian Yamit 199316), the annual profit is aX1 from Karangpilang roof tiles, aX2 from press tile and aX3 from Wuwung roof tiles.

3. Constraints (boundaries). In this study the limitations are:

a. Raw material

The raw materials in producing roof tiles are red earth, black soil, sand and kaolin which are the main parts of production activities. The size of the raw material is adjusted to each type of product using a comparison of each raw material in accordance with the specified size. In addition to the main ingredients, there are assistants including kerosene, pagoda oil and firewood.

Table 3 Raw Material Prices

\begin{tabular}{lcc}
\hline $\begin{array}{c}\text { Type of Raw } \\
\text { Material }\end{array}$ & $\begin{array}{c}\text { Capacity/Need } \\
\left(\mathbf{m}^{3}\right)\end{array}$ & Price Rp/ $\mathbf{m}^{3}$ \\
\hline Red soil & 6 & 70,000 \\
Black soil & 3 & 70,000 \\
Sand & 3,25 & 140,000 \\
Kaolin & 0,5 & 200,000 \\
\hline
\end{tabular}

Source: "Syukur” Tile Company Nganjuk, 2018

b. Manpower, i.e. is workers who are needed to conduct production activities. Measurement of labor in each section is the time required per unit of product is different. Labor costs have been determined by the company at Rp. 1,600 thousand.

c. Machine capacity, is the ability of a machine to produce production. Determined from each machine is the engine clock capacitance used to process the product per unit. The capacity of each machine for each product is (number of machines) $\mathrm{x}$ (day hours in 1 month) $\mathrm{x}$ (working hours) $\mathrm{x}$ (months in 1 year) $\mathrm{x}$ (60 minutes) $=$ capacity of machines available in one year.

d. Consumer demand, which is the amount demanded by consumers of each type of product in a period 2013-2017. to find out the existing demand limits used sales forecast using the linear trend method.

\section{Optimization of Product Combinations}

To find out the optimal product combination, this study uses a linear programming model with the simplex method, it needs to be determined first are:

1. The objective function (Objective Function) is to measure the contribution (contribution margin) of each product produced. The calculations on each product can be seen in the following table:

Table 4 Marginal Contribution Calculations "Syukur" Tile Company

\begin{tabular}{|c|c|c|c|c|c|c|}
\hline \multirow{2}{*}{$\begin{array}{l}\text { Types of } \\
\text { Products }\end{array}$} & \multirow{2}{*}{ Sale Price } & \multicolumn{3}{|c|}{ Variable } & \multirow{2}{*}{ Quantity } & \multirow{2}{*}{$\mathrm{CM}$} \\
\hline & & BB & TK & FOH & & \\
\hline Pressed tiles & 750,000 & 408,750 & 25,000 & 100,000 & 533,750 & 216,250 \\
\hline Coral tiles & 800,000 & 462,000 & 25,000 & 160,000 & 644,000 & 156,000 \\
\hline Wuwung tiles & $2,000,000$ & 462,000 & 25,000 & 150,000 & 637,000 & 1,363000 \\
\hline
\end{tabular}

Source: "Syukur" tile company Nganjuk, 2018

Description:

BB : Raw Materials

TK : Labor

FOH: Factory Overhead (indirect production costs)

CM : Contribution Margin (selling price-Variable Cost)

Then it can be seen the contribution margin of each product is

a) For tile press products: $\mathrm{Rp} 216,250$ 
Achmad Zaki \& Sinollah / The Implementation of Linear Program in Determining Product Combinations to Achieve Optimal Profits in Nganjuk "Syukur" Tile Home Industry / JEE, Vol. 9, No. 1, March 2020, pp 43-52

b) For Karangpilang Tile products: Rp156,000

c) For wuwung tile products: Rp1,363,000

Linear programming uses linearity assumptions by entering the Contribution margin of each product produced by the Nganjuk "Syukur" tile company: $\mathrm{X} 1=$ tile Press; $\mathrm{X} 2=$ Coral pilang tile; X3 = Wuwung roof tile. So that the objective function of the company can be formulated, namely maximizing profits in linear functions as follows: Maximum $\mathrm{Z}=\mathrm{X} 1+\mathrm{X} 2+\mathrm{X} 3$

\section{Limitation Function}

The company aims to achieve maximum profits and this condition is influenced by several factors, namely:

a) Limitation of Raw Materials

The need for raw materials in accordance with the requirements of each type of product used the same raw materials.

The amount of raw material available for the needs of one thousand seeds is:

$\mathrm{Rp} 140,000+\mathrm{Rp} 140,000+\mathrm{Rp} 140,000=$ Rp420,000

$\mathrm{Rp70,000}+\mathrm{Rp70,000}+\mathrm{Rp70,000}=$ Rp210,000

$\mathrm{Rp} 87,500+\mathrm{Rp} 70,000+\mathrm{Rp70,000}=$ Rp227,000

$\mathrm{Rp} 0+\mathrm{Rp} 50,000+\mathrm{Rp} 50,000=\mathrm{Rp} 100,000$

Medium materials available for red soil are Rp.448,000, for black soil Rp273,000 for sand Rp248,000, for kaolin Rp200,000.

b) Labor limitations.

Table 5 Calculation of Labor Costs for Tile Companies "Syukur" Nganjuk

\begin{tabular}{lccc}
\hline \multicolumn{4}{c}{ Bagian Cetak } \\
\hline $\begin{array}{c}\text { Types of } \\
\text { Products }\end{array}$ & Time/Unit & $\begin{array}{c}\text { Cost/Unit } \\
(\mathbf{R p})\end{array}$ & Cost \\
\hline Pressed tiles & 2 & 300 & 600 \\
Coral tiles & 2.20 & 300 & 660 \\
Wuwung tiles & 2.30 & 300 & 690 \\
\hline
\end{tabular}

\begin{tabular}{lccc}
\hline \multicolumn{4}{c}{ Others } \\
\hline $\begin{array}{c}\text { Types of } \\
\text { Products }\end{array}$ & Time/Unit & Cost/Unit & Cost \\
\hline Pressed tiles & 46.7 & 300 & 14.010 \\
Coral Tiles & 46.30 & 300 & 13.890 \\
Wuwung tiles & 46.20 & 300 & 13.860 \\
\hline \multicolumn{4}{c}{ Finishing } \\
\hline \multicolumn{1}{c}{ Types of } & Time/Unit & Cost/Unit & Cost \\
\hline Products & 1.30 & 300 & 390 \\
Cressed tiles & 1.50 & 300 & 450 \\
Wuwal Tiles & 1.5 & 300 & 450 \\
\hline
\end{tabular}

Source: "Syukur" Tile Company Nganjuk, 2018

\section{Labor costs}

Labor costs for each product unit are set at Rp300,000. This workforce is divided into three parts.

1) Print/Formation Section

In this section there are 5 workers, the number of hours worked a day is 7 hours. So the number of hours of labor the construction department per day is: 2,100 minutes.

a.1 Roof Tile (X1). Time required $=2$ minutes

a.2 Pilang reef tile (X2). Time required $=$ 2.20 minutes

a.3 Tile Wuwung (X3). Time required = 2.30 minutes

2) Other Parts

In other parts, there are 10 workers, the number of hours worked a day is 7 hours. So the total work hours of this section of labor per day is: 4,200 minutes

a.1 Tile Press (X1). time required $=46.7$ minutes

a.2 Karang Pilang Tile (X2). time required $=46.30$ minutes

a.3 Tile Wuwung (X3). time required $=46$, 20 minutes

3) Finishing Section

In the finishing section there are 5 workers, the number of hours worked a day is 7 
Achmad Zaki \& Sinollah / The Implementation of Linear Program in Determining Product Combinations to Achieve

Optimal Profits in Nganjuk "Syukur" Tile Home Industry / JEE, Vol. 9, No. 1, March 2020, pp 43-52

hours. So the number of hours of work the finishing day laborers are: 2,100 minutes.

a.1 Roof Tile (X1). time required $=1.30$ minutes

a.2 Pilang Karang tile (X2). time required = 1.50 minutes

a.3 Wuwung roof tile (X3). the time required is $=1.50$ minutes

Furthermore, each boundary can be formulated in the form of a linear function:

$2 \mathrm{X} 1+2.20 \mathrm{X} 2+2.30 \mathrm{X} 3 \leq 2,100$

$46.7 \mathrm{X} 1+46.30 \mathrm{X} 2+46.20 \mathrm{X} 3 \leq 4,200$

$1.30 \times 1+1.50 \times 2+1.50 \times 3 \leq 2.100$

\section{Engine Capacity}

The number of machines is two units, and the time available in a day is 7 working hours. $2 \times 7 \times 312 \times 60$ minutes $=262,080$ minutes While the time needed to produce tile is:

1) In one day producing tile press is $0.97 \mathrm{~min}-$ utes

2) In one day producing pilang reef tile is 0.97 minutes

3) In one day, producing wuwung roof tiles takes 2.22 minutes

Tabel 6 Tile Company Consumer Demand Data "Syukur" Nganjuk

\begin{tabular}{|c|c|c|c|c|c|}
\hline $\begin{array}{l}\text { Types of } \\
\text { Products }\end{array}$ & Year & $\mathrm{Y}$ & $X$ & xy & $\mathrm{X} 2$ \\
\hline \multirow{5}{*}{ Pressed tiles } & 2013 & 110,000 & -2 & $-220,000$ & 4 \\
\hline & 2014 & 120,000 & -1 & $-120,000$ & 1 \\
\hline & 2015 & 125,000 & 0 & 0 & 0 \\
\hline & 2016 & 128,000 & 1 & 128,000 & 1 \\
\hline & 2017 & 132,000 & 2 & 264,000 & 4 \\
\hline Total & & 615,000 & & 52,000 & 10 \\
\hline \multirow{5}{*}{ Coral tiles } & 2013 & 125,000 & -2 & $-250,000$ & 4 \\
\hline & 2014 & 127,000 & -1 & $-127,000$ & 1 \\
\hline & 2015 & 130,000 & 0 & 0 & 0 \\
\hline & 2016 & 132,000 & 1 & 132,000 & 1 \\
\hline & 2017 & 135,000 & 2 & 170,000 & 4 \\
\hline Total & & 649,000 & & 25,000 & 10 \\
\hline \multirow{5}{*}{ Wuwung tiles } & 2013 & 50,000 & -2 & $-100,000$ & 4 \\
\hline & 2014 & 52,000 & -1 & $-52,000$ & 1 \\
\hline & 2015 & 55,000 & 0 & 0 & 0 \\
\hline & 2016 & 56,000 & 1 & 56,000 & 1 \\
\hline & 2017 & 59,000 & 2 & 118,000 & 4 \\
\hline Total & & 272,000 & & 22,000 & 10 \\
\hline
\end{tabular}

Source: "Syukur" Tile Company Nganjuk, 2018

\section{Limitation of Request}

Limitation of demand is very important to determine a company's product combination in addition to the limits of labor and raw materials. To determine the existing demand limits, sales forecast is used using the linear trend method. And the calculation can be seen in the Table 6.

Based on the trend formula, values can be seen as shown in the following table:

\begin{tabular}{lccc}
\hline Types of Products & $\mathbf{a}$ & $\mathbf{b}$ & $\mathbf{Y}$ \\
\hline Pressed tiles & 123,000 & 5,200 & 143,800 \\
Coral tiles & 129,000 & 2,500 & 139,800 \\
Wuwung tiles & 54,400 & 2,200 & 63,200 \\
\hline
\end{tabular}

From these calculations, it can be predicted that sales per day in 2018 from each product are:

1) Press tile $=143,800: 312=460.9$

2) Pile reef tiles $=139,800: 312=448.1$

3) Wuwung roof tiles $=62,200: 312=202,5$

From the above demand limitation forecast, it can be formulated in the form of inequality as follows: $\mathrm{X} 1 \leq 460.9$; $\mathrm{X} 2 \leq 448.1$; $\mathrm{X} 3 \leq 202.5$. Where: $\mathrm{X} 1, \mathrm{X} 2, \mathrm{X} 3 \geq 0$

So from these data it can be formulated as a whole linear inequality as follows:

1. Limitation function

$\mathrm{Z} \operatorname{Max}=216,250 \mathrm{X} 1+156,000 \mathrm{X} 2+$ $1,363,000 \times 3$

2. Limitation function

a. Raw material

- Red soil $=7 \mathrm{X} 1+7 \mathrm{X} 2+7 \mathrm{X} 3 \leq$ 448,000

- Black soil $=3 \mathrm{X} 1+3 \mathrm{X} 2+3 \mathrm{X} 3 \leq$ 273,000

- Sand soil $=3,625 \mathrm{X} 1+2.9 \mathrm{X} 2+$ $2.9 \times 3 \leq 248,000$

- Kaolin $=\mathrm{X} 1+2.5 \mathrm{X} 2+2.5 \mathrm{X} 3 \leq$ 200,000 
Achmad Zaki \& Sinollah / The Implementation of Linear Program in Determining Product Combinations to Achieve Optimal Profits in Nganjuk "Syukur" Tile Home Industry / JEE, Vol. 9, No. 1, March 2020, pp 43-52

b. labor

- Printable section $=2 \mathrm{X} 1+2.20 \mathrm{X} 2+$ $2.30 \times 3 \leq 2.100$

- Other Parts $=46.7 \mathrm{X} 1+46.30 \mathrm{X} 2+$ $46.20 \times 3 \leq 4,200$

- Finishing $=1.30 \mathrm{X} 1+1.50 \mathrm{X} 2+$ $1.50 \times 3 \leq 2.100$

c. Engine capacity: $0.99 \mathrm{X} 1+0.97 \mathrm{X} 2+$ $2.22 \times 3 \leq 262,080$

d. Request

- X1 $\leq 460.9$

- $\mathrm{X} 2 \leq 448.1$

- $\mathrm{X} 3 \leq 202.5$

The company will be able to produce maximum profits if each type of product is known to be a combination of products:

1. Tile press $(\mathrm{X} 1)=341.09=341$ per day

2. Pilang reef tile $(\mathrm{X} 2)=448.1=448$ per day

3. Wuwung roof tiles $=202.5=203$ per day

While the products produced before using linear programming are: 1 . Press tile $(\mathrm{X} 1)=$ $335 ; 2$. Pilang reef tile $(X 2)=439$ and; 3 . Wuwung roof tiles $=203$

From the analysis the company can compare the maximum profit after using linear programming simplex method is as follows:

a. The advantage after using linear programming

$$
\begin{aligned}
& Z=216,250 X 1+156,000 X 2+ \\
& 1,363,000 \times 3 \\
= & 21.6250(335)+156,000(448)+ \\
& 1,363,000(203) \\
= & 72,360,000+69,888,000+276,689,000 \\
= & 418,937,000
\end{aligned}
$$

\section{b. Advantages before using}

$Z=216,250 X 1+156,000 X 2+1,363,000$ $\mathrm{X} 3$

$$
\begin{aligned}
= & 216,250(335)+156,000(439)+ \\
& 1,363,000(202) \\
= & 72,443,750+68,484,000+276,689,000 \\
= & 417,616,750
\end{aligned}
$$

This research was supported by research by Maelin (2010), Suprapti and Bodroastuti (201); Hakim et al. (2018); that using a linear program can optimize the product.

\section{DISCUSSION}

Based on the description and from the results of the discussion it can be concluded that: (1) In reality so far the Nganjuk "Syukur" tile company has not been optimal in carrying out product combinations; (2) It is necessary to determine the combination of products with the right calculation, if the company produces more than one type of product. After knowing the objective function and boundary function, in solving it using linear programming, so that it will be known the combination of products from the three products. With linear programming, there is an increase in profits that can be obtained by tile companies "Gratitude" Nganjuk. This study supports the research of Howara (2011), Rahayu et al (2014) and Ujianto (2016). To be able to obtain optimal profits, companies must pay attention to the combination of products with the right calculation, if the company produces more than one type of product (Krisnadewi and Setiawan, 2018). Likewise with the limiting factors.

One of the weaknesses in this study is that the discussion is done manually, to reduce errors in calculations it is recommended to use software such as POM-QM, LINDO and other software. Another weakness in this research in optimizing profits is only using a linear program, it would be 
Achmad Zaki \& Sinollah / The Implementation of Linear Program in Determining Product Combinations to Achieve Optimal Profits in Nganjuk "Syukur” Tile Home Industry / JEE, Vol. 9, No. 1, March 2020, pp 43-52

better if you can combine it with other analyzes such as cost analysis to determine net income that can be received and break-even point to find the maximum production unit.

\section{REFERENCES}

Agus Asyhari. (1986). Manajemen Produksi (Perencanaan System Produksi I). Yogyakarta: Penerbit BPFE UGM.

Agustina, Erni \& Sriwidadi, Teguh. (2013). Analisis Optimalisasi Produksi dengan Linear Programming Melalui Metode Simpleks. Binus Business Review, Vol. 4 No. 2, November 2013: 725-741.

Asri M. \& Widayat W. (1994). Linier Programming. Yogyakarta: BPFE UGM.

Arifinal A. Chaniago et al. (1994). Ekonomi. Bandung: Penerbit Angkasa.

Basu Swasta. (1986). Ekonomi Pembangunan. Surabaya: Usaha Bersama.

Buffa S. El Wood \& Sarin KR. (1996). Manajemen Operasi Produksi Modern. Jakarta: Binarupa Aksara.

Govindan, Kannan \& R. Sivakumar. (2016). Green Supplier Selection and Order Allocation in a Low-Carbon Paper Industry: Integrated Multi-Criteria Heterogeneous Decision-Making and Multi-Objective Linear Programming Approaches. Operation Research, 2(3), pp. 243-276.

Hakim, Lutfi, Hadi Paramu, \& Eka Bambang Gusminto. (2018). Penerapan Linear Programming dalam Penentuan Kombinasi Produk Guna Memaksimalkan Laba Pada UD Putera Sroedji Jember. Bisma: Jurnal Bisnis dan Manajemen, Volume 12 (3). Hal: $300-312$

Handoko T. Hani. (1984). Dasar-Dasar Manajemen Produksi dan Operasi, Edisi Pertama, Yogyakarta: BPFE.
Heizer, Jay \& Render, Barry. (2006). Operations Management. Jakarta: Salemba Empat.

Howara, Dafina. (2011). Optimalisasi Pengembangan Usaha Tani Tanaman Padi dan Ternak Sapi Secara Terpadu di Kabupaten Majalengka. J. Agroland, 18(1), hal. 4349.

Karo, Natalia Br. (2016). Analisis Optimasi Distribusi Beras Bulog di Provinsi Jawa Barat. Jurnal MIX, 7(1), hal. 103-120.

Keykhaei, Reza \& Jahandideh, Mohamad Taghi. (2012). Tangency Portfolio in the Linear Programming Solvable Portfolio Selection Models. Rairo Operation Research, 4(6), pp. 166-167.

Kotler, Philip \& Keller, Kevin Lane. (2007). Manajemen Pemasaran, Edisi 12. Jakarta: Indeks.

Krisnadewi, Ni Putu \& Setiawan, Putu Yudi. (2018). Optimalisasi Produksi pada Usaha Kecil Kripik Terry di Desa Nyanglan Kaja, Kecamatan Tembuku Kabupaten Bangli. Jurnal Manajemen, Volume 7 (11), hal: 6011-6040. DOI: https://doi.org/10.24843/ EJMUNUD.2018.v7.i11.p8

Maelin, Lydia. (2010). Penentuan Luas Produksi yang Optimal pada Produsen Genteng Super MD WNRT di Kecamatan Bantarbolang Kabupaten Pemalang. Skripsi. Semarang: Yayasan Widya Manggala.

Meng, Xuelei, Limin Jian, Wanli Xiang, \& Jie Xu. (2015). Train Re-Scheduling Based on an Improved Fuzzy Linear Programming Model. Keybernetes, 44(10), pp. 1472-1503.

Mulyono, S. (2004). Riset Operasi. Jakarta: Penerbitan Fakultas Ekonomi Universitas Indonesia.

Rahayu, Yuniarsi, Bowo Nurhadiyono, \& Dwi Nurul Izzhati. (2014). Analisis Linier Pro- 
Achmad Zaki \& Sinollah / The Implementation of Linear Program in Determining Product Combinations to Achieve Optimal Profits in Nganjuk "Syukur" Tile Home Industry / JEE, Vol. 9, No. 1, March 2020, pp 43-52

gramming untuk Optimalisasi Kombinasi

Produk. Techno, 13(4), hal. 232-237.

Riduwan \& Kuncoro, E. A. (2008). Cara Menggunakan dan Memaknai Analisis Jalur (Path Analysis). Bandung: Alfabeta.

Simamarta A. Dj. (1992). Operational Research Sebuah Pengantar Teknik-Teknik Optimasi Kuantitatif dan System Operasional. Yogyakarta: Penerbit BPFE UGM.

Sari, Mei L., Fitriyadi, \& Boy Abidin R. (2015).

Penerapan Metode Simpleks untuk Optimasi Produksi. Jurnal Progresif, 11(1), hal. 1117-1124.

Schreider, Sergei, Jonathan Plummer, Daniel McInnes, dan Boris Miller. (2015). Sensitivity Analysis of Gas Supply Optimization Models. Mathematical Science, 22(6), pp. 565-588.

Sinollah. (2012). Analisis Pengembangan dan Saluran Distribusi Susu Sapi di Perusahaan Karunia Kediri. Jurnal Manajemen Agribisnis, Volume 12(1). Hal: 51-67.

Stones J.A., Wankel C. (1986). Manajemen, Edisi ketiga. Jakarta: CV Intermedia.

Subagyo Pangstu, Asri M. \& Handoko T. Hani. (1992). Dasar-Dasar Operation Research, Cetakan kedelapan. Yogyakarta: BPFE.

Subiyanto \& Tim. (2002). Ekonomi. Surabaya: JP Press.

Sukanto R. \& Indriyo G. (1992). Manajemen Produksi. Yogyakarta: Penerbit BPFE.

Suprapti, Indri \& Bodoastuti, Tri. (2012). Penentuan Kombinasi Produk yang Optimal untuk Meningkatkan Laba pada CV Optima Semarang. Aset, Volume 14 (2). Hal: 121132.
Supranto J. (1983). Linier Programming, Edisi kedua. Jakarta: Penerbit LPFE UI. , (1993). Riset Operasi untuk Pengambilan Keputusan. Yogyakarta: Penerbit BPFE UIP.

Suryani, Endah Kurnia. (2006). Analisis Perencanaan dan Penentuan Kombinasi Produk Optimal untuk Memaksimalkan Laba dalam Pembangunan Perumahan Puri Pudak Payung Asri (p4a) di Semarang. Skripsi. Surakarta: Fakultas Ekonomi Universitas Sebelas Maret.

Ujianto, Bayu K. (2016). Optimasi Pemilihan Tipe Rumah dengan Teknik Linear Programming Studi Kasus: Pondok Sukun Cluster. Spectra, 12(27), hal. 53-64.

Veselovska, Ing. Lenka. (2014). Linear Programming Model of Production Process Optimization: A Case Study. The Business \& Management Review, 5(1), pp. 211-219.

Vijayvargy, Lokesh. (2015). Optimization of Resources in Supply Chain by Linear Programming: A Case of India's MSME. The IUP Journal of Supply Chain Management, 3(4), pp. 7-20.

Windarti, Tantri. (2013). Pemodelan Optimalisasi Produksi untuk Memaksimalkan Keuntungan dengan Menggunakan Metode Pemrograman Linier. Spektrum Industri. Volume 11 (2). Hal: 117-242.

Yamit Zulian. (1993). Manajemen Kuantitatif untuk Bisnis (Operation Research). Yogyakarta: Penerbit BPFE. 
Achmad Zaki \& Sinollah / The Implementation of Linear Program in Determining Product Combinations to Achieve Optimal Profits in Nganjuk "Syukur" Tile Home Industry / JEE, Vol. 9, No. 1, March 2020, pp 43-52 